\title{
Cytokines and Chemokines in Periodontitis
}

\author{
Doaa Elsayed Ramadan ${ }^{1}$ Ninuk Hariyani ${ }^{1,2} \quad$ Retno Indrawati ${ }^{1} \quad$ Rini Devijanti Ridwan ${ }^{1} \quad$ Indeswati Diyatri ${ }^{1}$ \\ ${ }^{1}$ Dental Health Science Postgraduate Program, Faculty of Dental \\ Medicine, Universitas Airlangga, Surabaya, Indonesia \\ 2Department of Dental Public Health, Faculty of Dental Medicine, \\ Universitas Airlangga, Indonesia \\ Address for correspondence Ninuk Hariyani, DDS, MPH, PhD, Dental \\ Health Science Postgraduate Program, Faculty of Dental Medicine, \\ Universitas Airlangga, Surabaya, Indonesia \\ (e-mail: ninuk_hariyani@yahoo.co.id).
}

Eur J Dent:2020;14:483-495

\begin{abstract}
Periodontitis is a common inflammatory periodontal disease affecting a wide range of population all over the world. The causing bacteria releases chemicals which activate the innate immune system to release proinflammatory cytokines contributing to more progression. This activates the acquired immune system leading to more progression of periodontitis. As the immune response goes on, released cytokines and chemokines can damage the periodontal ligaments, gingiva, and alveolar bone. There are many types of cytokines and chemokines in periodontitis. Cytokines are peptide mediators who are responsible for cell signaling and communication. Chemokines are a large subfamily of cytokines having the ability to coordinate leukocyte recruitment and activation. This paper is a narrative review of the literature.This review ensures that inflammatory mediators in the case of periodontitis can cause a noticeable damage in the whole apparatus of the periodontium. It causes soft tissue inflammation and bone damage affected by the mediators of both innate and acquired immune system. The inflammatory process is accompanied by large network of cytokines and

Keywords

- periodontitis

- inflammation

- mediators

- cytokines

- chemokines chemokines. There is high expression of proinflammatory cytokines such as interleukin (IL)-1 $\alpha$, IL-1 $\beta$, IL-6, IL-12, tumor necrosis factor (TNF)- $\alpha$, and regulatory cytokines such as IL-4, IL-1(RA) receptor antagonist, IL-10, and induced protein (IP)-10. There is also increased production of cytokines IL-10, IL-12, interferon- $\gamma$, IP-10, IL-1RA, and IL-4. Cytokines IL-17, IL-6, IL-1 $\beta$, TNF- $\alpha$, macrophage colony-stimulating factor, and prostaglandin $E_{2}$ trigger the osteoclast activity causing bone resorption.
\end{abstract}

\section{Introduction}

The periodontium is the whole collagenous apparatus surrounding the tooth structure. It is necessary to keep the tooth fixed to the underlying alveolar bone and sustained in its place for proper aesthetics and function. It is formed of four main components: gingiva, alveolar bone, cementum, and periodontal ligament. The mouth is full of uncountable number of bacteria, which includes a harmless type being essential for good oral hygiene and another pathogenic type causing periodontal diseases. ${ }^{1}$ The pathogenic bacteria form subgingival biofilm or dental plaque which causes inflammation that can last for many months if it is left without treatment causing soft tissue destruction and bone resorption. ${ }^{2}$
Periodontitis is known as an inflammatory disease attacking the periodontal apparatus on a very wide range of population all over the world. It is well known that periodontitis is a host-mediated process which includes osteoclastogenesis and destruction of soft tissue caused by the released enzymes responsible for tissue lysis. ${ }^{3}$ Periodontitis occurs as a result of the presence of anaerobic gram-negative bacteria. It has many different forms, but it has two main forms: aggressive periodontitis and chronic periodontitis. Aggressive periodontitis is a rapid progressive condition which affects up to $13 \%$ of the adults, while chronic periodontitis affects more than $30 \%$ of the adults with a relatively slower rate. ${ }^{4}$

Periodontitis is a multifactorial disease primarily caused by microbial biofilm containing different colonies of microorganisms. Clinically, periodontitis is associated with some 
characteristics such as increased probing depth, increased plaque index, reduced clinical attachment level, bleeding on probing, and obvious bone loss. ${ }^{5}$ It is assumed that periodontitis occurs due to a complex of genetic, environmental, and bacterial interaction in which bacterial and host factors play a critical role. The imbalance between these two factors results in a completely different change from health state to inflammatory disease. The imbalance can be represented into an increased plaque biofilm, a reduced host resistance, and an increased bacterial virulence. ${ }^{6}$

During periodontitis, the pathogen triggers the white blood cells of the innate immune system to release proinflammatory mediators such as cytokines that play a vital role in the progression of the inflammation process of periodontitis. In addition, these pathogens can activate the acquired immune system that contributes to more and more progression of the inflammatory condition. ${ }^{7}$ As the immune response continues, released cytokines and chemokines can severely damage the gingiva, periodontal ligaments, and alveolar bone. This causes permanent bone damage and irreversible periodontal attachment loss. ${ }^{8} \mathrm{~A}$ recent research showed that local periodontal inflammation may trigger systemic inflammatory condition causing some serious diseases such as rheumatoid arthritis, miscarriage, diabetes mellitus, pulmonary diseases, and cardiovascular diseases.?

Cytokines are highly important peptide mediators whose main function is cell signaling and communication. Functions of cytokines vary to include the control of cell proliferation, cell differentiation, immune responses, and inflammatory responses. Cytokines are defined as soluble small proteins $(\sim 5-20 \mathrm{kDa})$ which bind to definite receptors on specific cells, initiate some internal cellular changes, and cause various genetic and chemical regulations. Cytokines are produced by specific cells and affect the behavior of many other cells. ${ }^{9}$

Specific cytokines own a variety of activities such as paracrine, endocrine, and autocrine activity. Their activities are achieved by binding to definite receptors and giving different responses depending on the target cell and even the cytokine itself. ${ }^{10}$ They include chemokines which promote chemotaxis, interleukins which regulates the communication between white blood cells, interferons which regulate innate immunity, and lymphokines and tumor necrosis factor which have a proinflammatory activity. ${ }^{11}$

Chemokines are categorized as a large subfamily of cytokines having the ability to coordinate leukocyte recruitment and activation resulting in the pathogenesis of various human diseases that are regulated by the human immune system. They are categorized as inflammatory proteins with small molecular weight which own the ability to attract macrophages, neutrophils, and lymphocytes to the inflammation site. They are also called chemotactic cytokines due to their chemotactic property in nearby responsive cells. ${ }^{12}$

There are different common forms of inflammation and as we know every inflammatory process is driven by a series of inflammatory mediators. As periodontitis is one of the inflammatory processes, it is related with inflammatory mediators. This review will discuss these definite mediators. This review will reflect an overview of the pathogenesis of periodontitis and its causative organism. It shows how the human immune response plays an important role in periodontitis. It also discusses the whole inflammatory process of periodontitis and the main responsible inflammatory mediators.

\section{Literature Review}

\section{Periodontal Pathogenesis}

Chronic and aggressive periodontitis share many clinical features, but they somehow differ according to each form of periodontitis. However, it is stated that both forms are complex infections that are caused by adherence of bacterial biofilms on tooth structure in susceptible hosts. In both cases of periodontitis, the biofilms contain microorganisms that are considered the most effective factor of the disease occurrence. In addition, host immune reactions to these biofilms are primarily responsible for the severe bone damage and the massive attachment loss of the periodontal ligament supporting the tooth structure. ${ }^{13}$

The process of periodontal disease is initiated when bacteria colonize on the teeth cervical margin and form a subgingival plaque biofilm. Bacteria start to multiply making the plaque more mature which in turn causes an extensive percentage of gram-negative bacteria including Porphyromonas gingivalis and Aggregatibacter actinomycetemcomitans. ${ }^{14,15}$ These bacteria produce specific chemicals including hydrogen sulphide, proteases, and ammonia which cause a severe damage to the whole periodontium. Such important chemicals also serve to activate the immune system to produce proinflammatory cytokines which lead to tissue attachment loss and permanent alveolar bone damage. ${ }^{1}$

There is a strong relationship between the bone destruction in periodontal diseases and the causative subgingival colonies of bacteria. The inflammatory process of periodontal diseases is highly characterized by leucocytes infiltrations functioning to prevent more bacterial invasion. There are a lot of factors related to the recruitment of leucocytes such as cytokines, chemokines, bacterial products, lipid mediators, complements, and the cross-reaction between the two arms of human immune response: innate immune response and adaptive immune response. ${ }^{3}$

\section{Host Immune Response in Periodontitis}

The host immune response is driven by two main arms: innate immune response and adaptive immune response. Both innate and adaptive immunity normally work to help each other maintain healthy state and prevent diseases. Periodontitis is primarily caused by subgingival bacterial plaque formed by anaerobic gram-negative bacteria. This species include $A$. actinomycetemcomitans and $P$. gingivalis which cause aggressive periodontitis and chronic periodontitis, respectively. ${ }^{16}$

Damage in periodontitis can occur directly and indirectly. The direct damage occurs as a result of the released pathogenic chemicals, while the indirect one occurs due to the host immune response to the bacterial pathogenic chemicals. The pathogenic substances released by bacteria 
are various and include lipopolysaccharide, lipoteichoic acid, extracellular vesicles, enzymes such as hyaluronidase, proteinase and collagenase, toxins such as leukotoxins, and metabolites such as hydrogen sulfide. ${ }^{17,18}$ The causative bacteria also produce volatile sulfur compounds (VSCs), which include dimethyl sulfide, methyl mercaptan, and hydrogen sulfide. ${ }^{19}$ The pathologic periodontal bacteria contribute to the initiation of periodontitis, but progression of periodontitis is primarily regulated by interactions between the host immune response and bacterial factors. This is the severe and persistent indirect damage caused due to the activation or inhibition of the innate and acquired immune responses to pathogenic bacteria. ${ }^{20}$

Bacterial pathogens can be recognized by nonclonal receptors of the innate immune response called pattern recognition receptors (PRRs). Many previous studies stated that toll-like receptor (TLR) is a type of PRR which possesses the ability to recognize periodontal pathogens and regulate the innate responses to pathologic bacteria. ${ }^{21,22}$ It stated that this receptor type work as a connecting bridge between innate and adaptive host immunity. ${ }^{23}$

Beside bacteria and its pathogenic products in periodontitis, there are several risk factors which may affect the host immune response causing periodontal tissue damage and bone destruction. It was said that periodontitis is a complex of genetic, bacterial, and environmental interaction in which genetic, bacterial, and environmental factors play a critical role. The imbalance between these two factors results in an increase in the plaque biofilm, a drop in the host resistance, and an increase in the bacterial virulence. ${ }^{6}$

In addition to these factors, social factors also play an essential role in the prevalence of periodontitis. It was recorded that low standard of life increases the prevalence of periodontitis. ${ }^{24}$ Another risk factor which plays a critical role in periodontitis is the different human habits. It was stated that poor oral hygiene habits increase the risk of periodontitis. ${ }^{25}$ It was also proved that lifestyle habits such as smoking, dietary habits, and alcohol consumption highly affect periodontal health. It was stated that smoking is highly associated with periodontal diseases such as periodontitis. ${ }^{26,27}$ Alcohol consumption and unhealthy dietary habits also increase the occurrence of periodontitis. ${ }^{27}$ The important role of psychological factors in the occurrence of periodontitis cannot be ignored as well. It was mentioned that human psychological conditions such as stress, anxiety, and depression can affect the immune response which in turn increases the human susceptibility to periodontitis. ${ }^{28}$ In addition to the previous risk factors, there is a strong bilateral relation between systemic diseases and periodontitis. A lot of systemic diseases and their medications are critical risk factor for the occurrence of periodontitis. ${ }^{29}$ Diabetes mellitus is one of the systemic diseases which may be related to the progression or even initiation of periodontitis. ${ }^{28}$

\section{Innate Immunity}

In periodontitis, the innate immune response is accomplished by a group of specific immune cells and antimicrobial proteins known as the complement system. One of the innate immune cells is the phagocytes which have many types like natural killer cells, neutrophils, macrophages, and dendritic cells. Such cells own the ability migrate to the infection site as a result of the increased release of chemokines and cytokines. ${ }^{30}$

Periodontal bacteria trigger the host immune response which causes release of inflammatory mediators and cytokines in the periodontal tissues causing periodontal breakdown. ${ }^{31}$ It has been demonstrated that a large network of cytokines plays a critical role in the pathogenesis of periodontitis leading to soft tissue destruction and bone resorption. ${ }^{32}$ Presence of increased level of cytokines including interleukin (IL)-1 $\beta$, IL-6, IL-10, IL-12, interferon (IFN)- $\gamma$, induced protein (IP)-10, IL-1 receptor antagonist (RA), IL-4, and TNF- $\alpha$ accompanies the inflammatory process of periodontitis. There is also elevated expression of both proinflammatory cytokines including IL- $1 \beta$, IL-6, IL-12, TNF- $\alpha$, and regulatory cytokines including IL-4, IL-1RA, IL-10, and IP-10. ${ }^{33}$ The oral mucosa is lined with epithelial cells that are considered the first defense against bacterial pathogens including pathogen-associated molecular patterns. These oral epithelial cells are responsible for the expression of various PRRs like proteinase-activated receptors and TLRs having the ability to be attached to those patterns. ${ }^{34,35}$

In addition to epithelial cells, fibroblasts play an important role in the inflammatory process of periodontitis. They are the main immune cells normally produce collagens and proteins to form the extracellular matrix of tissues and invest blood vessels. During the inflammatory process of periodontitis, they play an important role in producing tissue degradation enzymes. ${ }^{36}$ Fibroblasts are essential for the pathogenesis process of periodontitis because they respond to the invasion of pathogens by expressing protease-activated receptors, extracellular TLRs and intracellular TLRs. ${ }^{37}$ Activated fibroblasts release extracellular matrix degrading enzymes such as matrix metalloproteinases and proinflammatory mediators such as IL-8, IL-6, chemokine ligand 8 (CXCL-8), and prostaglandin E2.38,39

Neutrophils are essential cells for the inflammatory process due to their ability to migrate into the infected tissues to clear the invading microorganisms. This is achieved in the presence of bacterial peptides or other proinflammatory chemotactic mediators like IL- 1 and IL- $8 .{ }^{40}$ Besides, neutrophils own the ability to phagocytose bacteria and microorganisms and create reactive oxygen species (ROS) to get rid of the bacterial pathogens. It was thought that extracellular microbes are controlled by neutrophil extracellular traps (NET) that are formed by the lysis of polymorphonuclear leukocytes (PMNs) and the release of antimicrobial peptides and DNA. ${ }^{41,42}$

However, neutrophils in the crevice of gingiva can engage the bacterial biofilms on tooth surfaces, but they definitely cannot clear the whole mass of periodontal microorganisms. ${ }^{43}$ Whether there are too many or too few triggered neutrophil cells, they are extremely important to cause periodontitis. ${ }^{44}$ On the other hand, excessive activation of neutrophils may produce elevated levels of toxic substances and ROS that define localized aggressive periodontitis. ${ }^{45}$ So, in 
all different types of periodontitis, neutrophils can lead to whether antimicrobial resistance or tissue damage.

\section{Adaptive Immunity}

The adaptive response of the immune system is distinguished by its specificity and memory cells. It owns the capacity to distinguish its cells from other cells of the body. Once it recognizes microbial pathogens by the suitable receptor on dendritic cells or macrophages, cytokines are released. Cytokines trigger $\mathrm{T}$ and B cells which finally stimulate the two indispensable arms of immune response; cell-mediated and humoral immune responses. Cell-mediated and humoral immune response always function together; the predominant earlier responses are done by the innate immune response that subsequently helps to activate the adaptive one. In both immunities, the resulted damage is almost limited by the specificity of the responses as they focus the specific adaptive immune system.

Cytokines and chemokines are quickly produced in the tissues of periodontal ligament and can be detected continuously in the gingival crevicular fluid. This fluid originates from the gingival capillaries and involves some essential immune cells resulting in its increase during inflammation. ${ }^{46}$ The serum antibodies including immunoglobulin (Ig)M, IgG, and IgA are predominantly produced in the adaptive immune response. In addition, enzymes and complement components also exist in this immune response. These cellular components and proteins enable the innate and adaptive immune responses to take place at the area of bacterial infection.

\section{The Inflammatory Process of Periodontitis Cytokines and Chemokines}

The presence of subgingival pathogens involved in periodontitis and their secreted chemicals trigger the immune system to act against these foreign substances. This activation does not only act against the pathogen, but it can also cause damage to the periodontium. The inflammatory process of periodontitis is initiated by the activation of TLRs. ${ }^{20}$ These are specific protein structures that are considered as crucial part of the wall of epithelial cells whose function is to discover molecules released by the pathologic bacteria. Many different types of TLRs exist such as TLR-2 and TLR4. TLR-2 is mainly functioned to recognize the lipoproteins and peptidoglycan components of the secretion of subgingival bacteria, while TLR-4 is mostly directed to recognize lipopolysaccharide of gram-negative bacteria which is the main causative bacterial species of periodontitis. ${ }^{47}$

Inflammation process is driven by a connected group of cytokines and chemokines released continuously by various immune cells. ${ }^{48}$ The qualitative nature of cytokines and their continuous release is usually regulated by subsets of $\mathrm{CD}^{+} \mathrm{T}$ lymphocytes which are called $\mathrm{T}$ helper cells. The different subsets of $\mathrm{T}$ helper cells are characterized by releasing different cytokine profiles with different functions in the host immune response, although it is not necessary that the release of cytokines is always related with only one $\mathrm{T}$ helper cell subset. These subsets produce different cytokines, such as interleukins, which are molecules that regulate the immune response and signal the release and proliferation of more white blood cells. ${ }^{7}$

Particularly, Th1 cells release some interleukins as TNF- $\alpha$, IL-12, IL-1, IL-2, and IFN- $\gamma$ inducing the cellular immune response. In addition, Th2 cells mainly produce IL-10, IL-5, IL-6, IL-4, and IL-13 inducing the humoral immune response. ${ }^{49}$ Finally, Th17 cells release mainly IL-17 which is basically involved in the initial inflammatory response against subgingival pathogens by encouraging rapid neutrophils recruitment. ${ }^{50}$

On one hand, cytokines are defined as proteins secreted by the inflammatory cells into the injured tissues responding to microbial compounds and other injuries through leucocytes recruitment. ${ }^{51}$ They are continuously produced by lymphocytes specially $\mathrm{CD} 4^{+} \mathrm{T}$ lymphocytes. Cytokines, with the help of prostaglandins, play a vital role to initiate and regulate the inflammatory process of periodontitis through activation and differentiation of osteoblasts, activation, and proliferation of fibroblasts and production of collagen and neovascularization. ${ }^{51}$ Inflammatory cytokines can be classified into two categories: the first one is associated with acute inflammation and the second is associated with chronic inflammation. ${ }^{52}$

Cytokines are involved in regulating the inflammatory response of periodontitis, which is regulated by a complex network of mediators and signaling pathways. ${ }^{11} \mathrm{~A}$ wide range of cytokines plays a vital role in the pathophysiology of periodontitis such as IL-1 $\beta$, IL-6, TNF- $\alpha$, and RANKL. In addition to the anti-inflammatory function of IL-10, it has a proinflammatory role in periodontitis as well., ${ }^{53}$ Both IL- $1 \alpha$ and IL-1 $\beta$ also proved to act as strong proinflammatory molecules. ${ }^{54}$

On the other hand, chemokines represent a large subfamily of cytokines that is composed of small proteins and associated with activation and migration of inflammatory cells such as macrophages, neutrophils, and lymphocytes. They include 44 members that can bind to one or more $21 \mathrm{G}$-protein-coupled receptors. ${ }^{55}$ Their ability to migrate to the inflammation sites is called "chemotaxis," which is the reason for calling them "chemokines." ${ }^{56}$ They are secreted by some outstanding cells in the periodontium which includes macrophages, fibroblasts, epithelial cells, endothelial cells, polymorphonuclear leukocytes, lymphocytes, osteoclasts, mast cells, and monocytes. ${ }^{3}$

Based on the ligand structures, chemokines consist of two major families: CXC and CC with their receptors and CXC chemokine receptor (CXCR) and CCR, respectively. ${ }^{57}$ These receptors are found and expressed on Th1 cells, Th2 cells, neutrophils, and monocytes. ${ }^{58}$

Most previous conducted recent studies stated that their expression is regulated by cytokines. ${ }^{59}$ For further specification, Th1 cells express chemokine receptors CCR5 and CXCR3, while Th2 cells mainly express CCR3 and CCR4. Monocytes and macrophages express CCR5 and CCR2 as well. ${ }^{60}$ In a previous research, it was stated that the $\mathrm{CC}$ chemokine receptors are found and expressed on a wider range of cells such as macrophages, monocytes, platelets, basophils, lymphocytes, and eosinophils. ${ }^{59}$ 


\section{Inflammatory Mediators and Bone Resorption}

The initial response to subgingival bacterial infection is the occurrence of inflammatory reaction locally which gradually triggers the innate system. Aggravation of this initial inflammatory process results in continuous release of cytokines and other inflammatory mediators which propagate the inflammation along the whole gingival tissues. The failure to stop this inflammation leads to expansion of the inflammation to include the alveolar bone as well as the periodontal soft tissues. $^{61}$

Bone resorption condition is a highly organized process that mainly depends on the differentiation of monocytes into osteoclasts, which are responsible for bone resorption. A healthy alveolar bone is formed through continuous processes of bone formation and bone resorption. On the other hand, this normal balance is directed toward the resorption process through a mechanism targeted to increase osteoclast activation in periodontitis. Cytokines such as IL-17, IL-6, IL-1 $\beta$, TNF- $\alpha$, macrophage colony-stimulating factor, and prostaglandin $\mathrm{E}_{2}$ are numerous proinflammatory mediators which are capable of triggering osteoclast activity causing bone resorption. ${ }^{62}$

During the inflammatory response, a wide array of cytokines, chemokines, and many other inflammatory mediators activate periosteal osteoblasts altering expression levels of a protein presents on the osteoblast surfaces called receptor activator of nuclear factor-kappa B ligand. ${ }^{63,64}$ RANKL is a TNF- $\alpha$ family of cytokines induces the differentiation of osteoclasts, which are indispensable for the induction of osteoclastogenesis process. ${ }^{65}$

In patients with periodontitis, it is detected that the gingival crevicular fluid contains reduced osteoprotegerin levels and elevated levels of RANKL. Osteoprotegerin acts as a decoy receptor for RANKL with which RANKL interacts during the inflammatory process. RANKL then is attached to TNF- $\alpha$ on osteoclast lineage cells to control their differentiation into osteoclasts. RANKL is expressed by osteoblasts beside some other cells such as $\mathrm{T}$ lymphocytes, fibroblasts, and B lymphocytes. ${ }^{66}$

TNF- $\alpha$ and IL- 1 trigger bone resorption by controlling the osteoclast formation and keeping it in a continuous increase. IL- 1 also affects the osteoclastogenic effect of TNF- $\alpha$ by reinforcing the differentiation of osteoclast precursors and the expression of RANKL. Cytokines like IL-1 $\beta$ play a vital role as it induces RANKL expression of osteoprotegerin in various cells which include osteoblasts, periodontal ligament fibroblasts, and gingival fibroblasts. In the same way, IL-6 is produced by different cells such as osteoblasts and fibroblasts. It plays an extremely important role in inducing osteoclast formation and promoting bone resorption. ${ }^{62}$

In addition, the inflammatory mediator prostaglandin $\mathrm{E}_{2}$ is very necessary for this process. It triggers bone resorption by the upregulation of RANKL expression and the inhibition of OPG expression in osteoblastic cells. It was stated that the stimulatory effect of subgingival pathogens has been mediated through the PGE/RANKL pathway during osteoclastogenesis. It was stated that RANKL-stimulated osteoclastogenesis can be reinforced by lipopolysaccharide (LPS) and
$\mathrm{PGE}_{2}$ through a series of direct effects on the hematopoietic cells. It was also proved that $\mathrm{PGE}_{2}$ can inhibit and activate OPG expression, a contradiction which originates as a result of differing incubation times; it has been showed that $\mathrm{PGE}_{2}$ can affect osteoclast formation. ${ }^{67}$

\section{Discussion}

This review article presents numerous types of cytokines and chemokines and their vital role in the inflammatory process of periodontitis. The summary of the related available literatures is presented in - Table 1. Periodontitis is an inflammation of the periodontium which supports the tooth structure. Gram-negative bacteria including A. actinomycetemcomitans and $P$. gingivalis cause aggressive periodontitis and chronic periodontitis, respectively. ${ }^{16}$ This inflammatory disease leads to soft tissue destruction, bone resorption, and eventually intrabony defects. The damage caused in periodontitis is not only due to the presence of bacteria, but it also occurs as a result of the host immune response to these bacteria. ${ }^{68}$

Bacteria start the inflammatory process as they colonize on the tooth structures and start to multiply producing specific chemicals such as hydrogen sulphide, proteases, and ammonia which cause direct damage to the periodontium. The following indirect damage occurs when these chemicals activate the immune system to produce proinflammatory cytokines causing tissue attachment loss and alveolar bone damage. ${ }^{1}$ Both arms of the immune system; innate immune response and adaptive immune response take part in the inflammatory process of periodontitis..$^{30}$ It was stated that the inflammatory process of periodontitis is accompanied by increased release of cytokines and chemokines causing soft tissue destruction and bone resorption. ${ }^{32}$

Cytokines are proteins secreted by inflammatory cells into the injured tissues responding to microbial compounds through leucocytes recruitment. ${ }^{51}$ Cytokines play a vital role in the inflammatory process of periodontitis such as IL-1 $\beta$, IL- 6 , TNF- $\alpha$, and RANKL. ${ }^{33}$ It was proved that during periodontitis, there is also high expression of proinflammatory cytokines such as IL- $1 \alpha$, IL- $1 \beta$, IL- 6 , IL-12, TNF- $\alpha$, and regulatory cytokines such as IL-4, IL-1RA, IL-10, and IP-10. ${ }^{33}$ It was also stated that periodontitis is associated with increased production of cytokines such as IL-10, IL-12, IFN- $\gamma$, IP-10, IL-1RA, and IL- $4 .{ }^{54}$ In addition, cytokines such as IL-17, IL-6, IL-1 $\beta$, TNF- $\alpha$, macrophage colony-stimulating factor, and prostaglandin $\mathrm{E}_{2}$ are proinflammatory mediators which trigger the osteoclast activity causing bone resorption. ${ }^{62}$

Regarding chemokines, chemokines are a large subfamily of cytokines composed of small proteins and associated with activation and migration of inflammatory cells such as macrophages, neutrophils, and lymphocytes. They include 44 members that can bind to one or more $21 \mathrm{G}$-protein-coupled receptors. ${ }^{55}$ They are called "chemokines" because of their ability to migrate to the inflammation sites "chemotaxis." Chemokines are divided into two major families: CXC and CC with their receptors and CXCR and CCR, respectively. ${ }^{57}$ 
Table 1 Summary of the related available literature discussing the role of cytokines and chemokines in periodontitis

\begin{tabular}{|c|c|c|c|c|c|}
\hline No. & Study (y) & Literature title & $\begin{array}{l}\text { Literature } \\
\text { source }\end{array}$ & $\begin{array}{l}\text { Topic in this } \\
\text { article }\end{array}$ & Findings \\
\hline 1 & $\begin{array}{l}\text { Armitage and } \\
\text { Cullinan }^{13} \\
(2010)\end{array}$ & $\begin{array}{l}\text { Comparison of the } \\
\text { clinical features of } \\
\text { chronic and aggressive } \\
\text { periodontitis }\end{array}$ & Journal article & $\begin{array}{l}\text { Periodontal } \\
\text { pathogenesis }\end{array}$ & $\begin{array}{l}\text { Biofilm is considered the most effective factor } \\
\text { of the disease occurrence. In addition, host } \\
\text { immune response to these biofilms is also } \\
\text { responsible for the severe bone damage and the } \\
\text { massive periodontal attachment loss. }\end{array}$ \\
\hline 2 & $\begin{array}{l}\text { Socransky } \\
\text { et } \mathrm{al}^{14}(1998)\end{array}$ & $\begin{array}{l}\text { Microbial complexes in } \\
\text { subgingival plaque }\end{array}$ & Journal article & $\begin{array}{l}\text { Periodontal } \\
\text { pathogenesis }\end{array}$ & $\begin{array}{l}\text { Gram negative bacteria including Porphyromonas } \\
\text { gingivalis and Aggregatibacter actinomycetem- } \\
\text { comitans are the causative microorganisms of } \\
\text { periodontitis. }\end{array}$ \\
\hline 3 & $\begin{array}{l}\text { Balashova } \\
\text { et } \text { al }^{15}(2016)\end{array}$ & $\begin{array}{l}\text { A. actinomycetemcomi- } \\
\text { tans leukotoxin induces } \\
\text { cytosol acidification } \\
\text { in LFA- } 1 \text { expressing } \\
\text { immune cells }\end{array}$ & Journal article & $\begin{array}{l}\text { Periodontal } \\
\text { pathogenesis }\end{array}$ & $\begin{array}{l}\text { Gram negative bacteria such as A. actinomycet- } \\
\text { emcomitans is one of the main causative micro- } \\
\text { organisms of periodontitis. }\end{array}$ \\
\hline 4 & $\begin{array}{l}\text { Newman et al }{ }^{1} \\
(2011)\end{array}$ & $\begin{array}{l}\text { Carranza's clinical } \\
\text { periodontology }\end{array}$ & Textbook & $\begin{array}{l}\text { Periodontal } \\
\text { pathogenesis }\end{array}$ & $\begin{array}{l}\text { Bacteria produce specific chemicals which } \\
\text { damage the periodontium. These chemicals also } \\
\text { activate the immune system to produce proin- } \\
\text { flammatory cytokines leading to attachment loss } \\
\text { and alveolar bone damage. }\end{array}$ \\
\hline 5 & Graves $^{3}$ (2008) & $\begin{array}{l}\text { Cytokines that promote } \\
\text { periodontal tissue } \\
\text { destruction }\end{array}$ & Journal article & $\begin{array}{l}\text { Periodontal } \\
\text { pathogenesis } \\
\text { Cytokines and } \\
\text { chemokines }\end{array}$ & $\begin{array}{l}\text { The inflammatory process is characterized } \\
\text { by leucocytes infiltrations. There are factors } \\
\text { related to the recruitment of leucocytes such as } \\
\text { cytokines and chemokines. } \\
\text { Chemokines are secreted by some outstanding } \\
\text { cells in the periodontium which includes mac- } \\
\text { rophages, fibroblasts, epithelial cells, endothelial } \\
\text { cells, polymorphonuclear leukocytes, lympho- } \\
\text { cytes, osteoclasts, mast cells, and monocytes. }\end{array}$ \\
\hline 6 & $\begin{array}{l}\text { Gölz et al }{ }^{16} \\
\text { (2014) }\end{array}$ & $\begin{array}{l}\text { LPS from } P \text {. gingivalis and } \\
\text { hypoxia increases oxida- } \\
\text { tive stress in periodontal } \\
\text { ligament fibroblasts } \\
\text { and contributes to } \\
\text { periodontitis }\end{array}$ & Journal article & $\begin{array}{l}\text { Host immune } \\
\text { response in } \\
\text { periodontitis }\end{array}$ & P. gingivalis bacteria cause chronic periodontitis \\
\hline 7 & $\begin{array}{l}\text { Sorsa et al }{ }^{17} \\
(2011)\end{array}$ & $\begin{array}{l}\text { MMP activation in } \\
\text { diagnostics of perio- } \\
\text { dontitis and systemic } \\
\text { inflammation }\end{array}$ & Journal article & $\begin{array}{l}\text { Host immune } \\
\text { response in } \\
\text { periodontitis }\end{array}$ & \multirow{2}{*}{$\begin{array}{l}\text { Bacteria release lipopolysaccharide, lipoteichoic } \\
\text { acid, extracellular vesicles, enzymes such as hya- } \\
\text { luronidase, proteinase and collagenase, toxins as } \\
\text { leukotoxins, and metabolites such as hydrogen } \\
\text { sulfide. }\end{array}$} \\
\hline 8 & $\begin{array}{l}\text { Kachlany }{ }^{18} \\
(2010)\end{array}$ & $\begin{array}{l}\text { A. actinomycetemcom- } \\
\text { itans leukotoxin: from } \\
\text { threat to therapy }\end{array}$ & Journal article & $\begin{array}{l}\text { Host immune } \\
\text { response in } \\
\text { periodontitis }\end{array}$ & \\
\hline 9 & $\begin{array}{l}\text { Kapoor et al }{ }^{19} \\
(2016)\end{array}$ & $\begin{array}{l}\text { Halitosis: current con- } \\
\text { cepts on etiology, diag- } \\
\text { nosis and management }\end{array}$ & Journal article & $\begin{array}{l}\text { Host immune } \\
\text { response in } \\
\text { periodontitis }\end{array}$ & $\begin{array}{l}\text { Periodontitis is associated with production of } \\
\text { volatile sulfur compounds such as dimethyl } \\
\text { sulfide, methyl mercaptan, and hydrogen sulfide. }\end{array}$ \\
\hline 10 & $\begin{array}{l}\text { Song et al20 } \\
(2017)\end{array}$ & $\begin{array}{l}\text { The role of toll- } \\
\text { like receptors in } \\
\text { periodontitis }\end{array}$ & Journal article & $\begin{array}{l}\text { Host immune } \\
\text { response in } \\
\text { periodontitis }\end{array}$ & $\begin{array}{l}\text { The indirect damage caused due to the acti- } \\
\text { vation or inhibition of the innate and acquired } \\
\text { immune responses to pathogenic bacteria. }\end{array}$ \\
\hline 11 & $\begin{array}{l}\text { Zhang and } \mathrm{Li}^{21} \\
(2015)\end{array}$ & $\begin{array}{l}\text { Lipopolysaccharide- } \\
\text { regulated production of } \\
\text { bone sialoprotein and } \\
\text { interleukin- } 8 \text { in human } \\
\text { periodontal ligament } \\
\text { fibroblasts: the role } \\
\text { of toll-like receptors } 2 \\
\text { and } 4 \text { and the MAPK } \\
\text { pathway }\end{array}$ & Journal article & $\begin{array}{l}\text { Host immune } \\
\text { response in } \\
\text { periodontitis }\end{array}$ & $\begin{array}{l}\text { Toll-like receptor is a type of pattern recognition } \\
\text { receptor which possess the ability to recognize } \\
\text { periodontal pathogens and regulate the innate } \\
\text { responses to pathologic bacteria. }\end{array}$ \\
\hline 12 & $\begin{array}{l}\text { Wara-aswapati } \\
\text { et } \mathrm{al}^{22}(2013)\end{array}$ & $\begin{array}{l}\text { Induction of toll-like } \\
\text { receptor expression by } P . \\
\text { gingivalis }\end{array}$ & Journal article & $\begin{array}{l}\text { Host immune } \\
\text { response in } \\
\text { periodontitis }\end{array}$ & $\begin{array}{l}\text { Toll-like receptors possess the ability to recog- } \\
\text { nize periodontal pathogens and regulate the } \\
\text { innate immune response to pathologic bacteria. }\end{array}$ \\
\hline 13 & $\begin{array}{l}\text { Kawai et al }{ }^{23} \\
(2006)\end{array}$ & TLR signaling & Journal article & $\begin{array}{l}\text { Host immune } \\
\text { response in } \\
\text { periodontitis }\end{array}$ & $\begin{array}{l}\text { Toll-like receptors work as a connecting bridge } \\
\text { between innate and adaptive host immunity. }\end{array}$ \\
\hline
\end{tabular}


Table 1 (continued)

\begin{tabular}{|c|c|c|c|c|c|}
\hline No. & Study (y) & Literature title & $\begin{array}{l}\text { Literature } \\
\text { source }\end{array}$ & $\begin{array}{l}\text { Topic in this } \\
\text { article }\end{array}$ & Findings \\
\hline 14 & $\begin{array}{l}\text { Hasan and } \\
\text { Palmer }^{6}(2014)\end{array}$ & $\begin{array}{l}\text { A clinical guide to perio- } \\
\text { dontology: pathology of } \\
\text { periodontal disease }\end{array}$ & Journal article & $\begin{array}{l}\text { Host immune } \\
\text { response in } \\
\text { periodontitis }\end{array}$ & $\begin{array}{l}\text { Periodontitis is a complex of genetic, bacterial, } \\
\text { and environmental interactions. } \\
\text { The imbalance between bacteria and immune } \\
\text { response results in an increase in the plaque } \\
\text { biofilm, a drop in the host resistance, and an } \\
\text { increase in the bacterial virulence. }\end{array}$ \\
\hline 15 & $\begin{array}{l}\text { Schuch et } \mathrm{al}^{24} \\
(2018)\end{array}$ & $\begin{array}{l}\text { Effect of life-course fam- } \\
\text { ily income trajectories } \\
\text { on periodontitis: birth } \\
\text { cohort study }\end{array}$ & Journal article & $\begin{array}{l}\text { Host immune } \\
\text { response in } \\
\text { periodontitis }\end{array}$ & $\begin{array}{l}\text { Social factors also play an essential role in the } \\
\text { prevalence of periodontitis. Low standard of life } \\
\text { increases the prevalence of periodontitis. }\end{array}$ \\
\hline 16 & $\begin{array}{l}\text { Lertpimonchai } \\
\text { et } \mathrm{al}^{25}(2017)\end{array}$ & $\begin{array}{l}\text { The association } \\
\text { between oral hygiene } \\
\text { and periodontitis: a } \\
\text { systematic review and } \\
\text { meta-analysis }\end{array}$ & Journal Article & $\begin{array}{l}\text { Host immune } \\
\text { response in } \\
\text { periodontitis }\end{array}$ & $\begin{array}{l}\text { Poor oral hygiene habits increase the risk of } \\
\text { periodontitis. }\end{array}$ \\
\hline 17 & $\begin{array}{l}\text { Sakki et al27 } \\
\text { (1995) }\end{array}$ & $\begin{array}{l}\text { Association of lifestyle } \\
\text { with periodontal health }\end{array}$ & Journal article & $\begin{array}{l}\text { Host immune } \\
\text { response in } \\
\text { periodontitis }\end{array}$ & $\begin{array}{l}\text { Alcohol consumption and unhealthy dietary hab- } \\
\text { its increase the occurrence of periodontitis. }\end{array}$ \\
\hline 18 & $\begin{array}{l}\text { Nazir and } \\
\text { Almas }^{26}(2019)\end{array}$ & $\begin{array}{l}\text { Awareness about the } \\
\text { effects of tobacco con- } \\
\text { sumption on oral health } \\
\text { and the possibility } \\
\text { of smoking behavior } \\
\text { among male Saudi } \\
\text { schoolchildren }\end{array}$ & Journal article & $\begin{array}{l}\text { Host immune } \\
\text { response in } \\
\text { periodontitis }\end{array}$ & $\begin{array}{l}\text { It was also stated that smoking is highly associ- } \\
\text { ated with the occurrence of periodontal diseases } \\
\text { such as periodontitis. }\end{array}$ \\
\hline 19 & $\begin{array}{l}\text { Castro et } \mathrm{al}^{28} \\
(2020)\end{array}$ & $\begin{array}{l}\text { Association between } \\
\text { Psychological Stress and } \\
\text { Periodontitis: a system- } \\
\text { atic review }\end{array}$ & Journal article & $\begin{array}{l}\text { Host immune } \\
\text { response in } \\
\text { periodontitis }\end{array}$ & $\begin{array}{l}\text { Human psychological conditions such as stress, } \\
\text { anxiety, and depression can affect the immune } \\
\text { response which-in turn-increases the human } \\
\text { susceptibility to periodontitis. }\end{array}$ \\
\hline 20 & $\begin{array}{l}\text { Kim and } \\
\operatorname{Amar}^{29}(2006)\end{array}$ & $\begin{array}{l}\text { Periodontal disease } \\
\text { and systemic condi- } \\
\text { tions: a bidirectional } \\
\text { relationship }\end{array}$ & Journal article & $\begin{array}{l}\text { Host immune } \\
\text { response in } \\
\text { periodontitis }\end{array}$ & $\begin{array}{l}\text { There is a strong bilateral relation between } \\
\text { systemic diseases and periodontitis. A lot of sys- } \\
\text { temic diseases and their medications are critical } \\
\text { risk factor for the occurrence of periodontitis. }\end{array}$ \\
\hline 21 & $\begin{array}{l}\text { Meyle et al }{ }^{30} \\
(2017)\end{array}$ & $\begin{array}{l}\text { The innate host } \\
\text { response in caries and } \\
\text { periodontitis }\end{array}$ & Journal article & Innate immunity & $\begin{array}{l}\text { One of the innate immune cells is the phago- } \\
\text { cytes which have many types like natural killer } \\
\text { cells, neutrophils, macrophages, and dendritic } \\
\text { cells. Such cells can migrate to the infection site } \\
\text { as a result of the increased release of chemok- } \\
\text { ines and cytokines. }\end{array}$ \\
\hline 22 & $\begin{array}{l}\text { Kumaresan } \\
\text { et } a^{13}(2016)\end{array}$ & $\begin{array}{l}\text { Gingival crevicular } \\
\text { fluid periostin levels in } \\
\text { chronic periodontitis } \\
\text { patients following } \\
\text { nonsurgical periodontal } \\
\text { treatment with low-level } \\
\text { laser therapy }\end{array}$ & Journal article & Innate immunity & $\begin{array}{l}\text { Periodontal bacteria trigger the host immune } \\
\text { response which causes release of inflammatory } \\
\text { mediators and cytokines in the periodontal } \\
\text { tissues causing periodontal breakdown. }\end{array}$ \\
\hline 23 & $\begin{array}{l}\text { Lindhe et } \mathrm{al}^{32} \\
(2003)\end{array}$ & $\begin{array}{l}\text { Clinical periodontology } \\
\text { and implant dentistry }\end{array}$ & Textbook & Innate immunity & $\begin{array}{l}\text { A large network of cytokines plays a critical role } \\
\text { in the pathogenesis of periodontitis leading to } \\
\text { soft tissue destruction and bone resorption. }\end{array}$ \\
\hline 24 & $\begin{array}{l}\text { Cairo et al }{ }^{33} \\
(2010)\end{array}$ & $\begin{array}{l}\text { Markers of systemic } \\
\text { inflammation in perio- } \\
\text { dontal patients: chronic } \\
\text { versus aggressive perio- } \\
\text { dontitis. An explorative } \\
\text { cross-sectional study }\end{array}$ & Journal article & Innate immunity & $\begin{array}{l}\text { Presence of increased level of cytokines including } \\
\text { IL-1 } 1 \beta \text {, IL- } 6 \text {, IL-10, IL-12, IFN- } \gamma \text {, IP-10, IL-1RA, } \\
\text { IL-4, and TNF- } \alpha \text { accompanies the inflammatory } \\
\text { process of periodontitis. There is also elevated } \\
\text { expression of both proinflammatory cytokines } \\
\text { including IL-1 } 1 \beta \text {, IL-6, IL-12, TNF- } \alpha \text {, and regulatory } \\
\text { cytokines including IL-4, IL-1RA, IL-10, and IP-10. }\end{array}$ \\
\hline 25 & $\begin{array}{l}\text { Giacaman et } \\
\mathrm{al}^{34}(2009)\end{array}$ & $\begin{array}{l}\text { Cleavage of pro- } \\
\text { tease-activated recep- } \\
\text { tors on an immortalized } \\
\text { oral epithelial cell line by } \\
P . \text { gingivalis gingipains }\end{array}$ & Journal article & Innate immunity & $\begin{array}{l}\text { The oral mucosa is lined with epithelial cells that } \\
\text { are considered the first defense against bacterial } \\
\text { pathogens including pathogen-associated } \\
\text { molecular patterns. }\end{array}$ \\
\hline
\end{tabular}


Table 1 (continued)

\begin{tabular}{|c|c|c|c|c|c|}
\hline No. & Study (y) & Literature title & $\begin{array}{l}\text { Literature } \\
\text { source }\end{array}$ & $\begin{array}{l}\text { Topic in this } \\
\text { article }\end{array}$ & Findings \\
\hline 26 & $\begin{array}{l}\text { Beklen et } \mathrm{al}^{35} \\
(2008)\end{array}$ & $\begin{array}{l}\text { Immunohistochemical } \\
\text { localization of toll- } \\
\text { like receptors } 1-10 \text { in } \\
\text { periodontitis }\end{array}$ & Journal article & Innate immunity & $\begin{array}{l}\text { These oral epithelial cells are responsible for } \\
\text { the expression of various pattern recognition } \\
\text { receptors like proteinase-activated receptors } \\
\text { and toll-like receptors having the ability to be } \\
\text { attached to those patterns. }\end{array}$ \\
\hline 27 & $\begin{array}{l}\text { Dommisch } \\
\text { et } \mathrm{al}^{36}(2012)\end{array}$ & $\begin{array}{l}\text { Antimicrobial responses } \\
\text { of primary gingival cells } \\
\text { to } P \text {. gingivalis. }\end{array}$ & Journal article & Innate immunity & $\begin{array}{l}\text { Fibroblasts are the main immune cells normally } \\
\text { produce collagens and proteins to form the } \\
\text { extracellular matrix of tissues and invest blood } \\
\text { vessels. During the inflammatory process of } \\
\text { periodontitis, they play an important role in } \\
\text { producing tissue degradation enzymes. }\end{array}$ \\
\hline 28 & $\begin{array}{l}\text { Hosokawa } \\
\text { et } \mathrm{al}^{17}(2010)\end{array}$ & $\begin{array}{l}\text { Proinflammatory effects } \\
\text { of muramyldipeptide } \\
\text { on human gingival } \\
\text { fibroblasts }\end{array}$ & Journal article & Innate immunity & $\begin{array}{l}\text { Fibroblasts are essential for the pathogenesis } \\
\text { process of periodontitis because they respond } \\
\text { to the invasion of pathogens by expressing pro- } \\
\text { tease-activated receptors, extracellular toll-like } \\
\text { receptors and intracellular toll-like receptors. }\end{array}$ \\
\hline 29 & $\begin{array}{l}\text { Baek et al }{ }^{38} \\
(2013)\end{array}$ & $\begin{array}{l}\text { Gingival fibroblasts from } \\
\text { periodontitis patients } \\
\text { exhibit inflammatory } \\
\text { characteristics in vitro }\end{array}$ & Journal article & Innate immunity & $\begin{array}{l}\text { Activated fibroblasts release extracellular matrix } \\
\text { degrading enzymes such as matrix metalloprotein- } \\
\text { ases and proinflammatory mediators such as IL-8, } \\
\text { IL-6, chemokine ligand 8, and prostaglandin E2. }\end{array}$ \\
\hline 30 & $\begin{array}{l}\text { Marki et al }{ }^{40} \\
(2015)\end{array}$ & $\begin{array}{l}\text { Role of the endothelial } \\
\text { surface layer in neutro- } \\
\text { phil recruitment }\end{array}$ & Journal article & Innate immunity & $\begin{array}{l}\text { Neutrophils are essential cells for the inflammatory } \\
\text { process due to their ability to migrate into the } \\
\text { infected tissues to clear the invading microorgan- } \\
\text { isms. This is achieved in the presence of bacterial } \\
\text { peptides or other proinflammatory chemotactic } \\
\text { mediators like IL- } 1 \text { and IL-8. }\end{array}$ \\
\hline 31 & $\begin{array}{l}\text { White et } \mathrm{al}^{41} \\
(2014)\end{array}$ & $\begin{array}{l}\text { Differential activation of } \\
\text { neutrophil extracellular } \\
\text { traps by specific perio- } \\
\text { dontal bacteria }\end{array}$ & Journal article & Innate immunity & $\begin{array}{l}\text { Neutrophils own the ability to phagocytose } \\
\text { bacteria and microorganisms. }\end{array}$ \\
\hline 32 & $\begin{array}{l}\text { White et al }{ }^{42} \\
(2016)\end{array}$ & $\begin{array}{l}\text { Neutrophil extracellular } \\
\text { traps in periodontitis: a } \\
\text { web of intrigue }\end{array}$ & Journal article & Innate immunity & $\begin{array}{l}\text { Extracellular microbes are controlled by neutro- } \\
\text { phil extracellular traps that are formed by the } \\
\text { lysis of PMNs and the release of antimicrobial } \\
\text { peptides and DNA. }\end{array}$ \\
\hline 33 & $\begin{array}{l}\text { Alfakry et al }{ }^{43} \\
(2016)\end{array}$ & $\begin{array}{l}\text { Neutrophil proteolytic } \\
\text { activation cascades: a } \\
\text { possible mechanistic } \\
\text { link between chronic } \\
\text { periodontitis and coro- } \\
\text { nary heart disease }\end{array}$ & Journal article & Innate immunity & $\begin{array}{l}\text { Neutrophils in the crevice of gingiva can engage } \\
\text { the bacterial biofilms on tooth surfaces but they } \\
\text { definitely cannot clear the whole mass of perio- } \\
\text { dontal microorganisms. }\end{array}$ \\
\hline 34 & $\begin{array}{l}\text { Hajishengallis } \\
\text { et } \mathrm{al}^{44}(2015)\end{array}$ & $\begin{array}{l}\text { Neutrophil homeostasis } \\
\text { and inflammation: novel } \\
\text { paradigms from study- } \\
\text { ing periodontitis }\end{array}$ & Journal article & Innate immunity & $\begin{array}{l}\text { Whether there are too many or too few triggered } \\
\text { neutrophil cells, they are extremely important to } \\
\text { cause periodontitis. }\end{array}$ \\
\hline 35 & $\begin{array}{l}\text { Hasturk and } \\
\text { Kantarci }^{45} \\
(2015)\end{array}$ & $\begin{array}{l}\text { Activation and reso- } \\
\text { lution of periodontal } \\
\text { inflammation and its } \\
\text { systemic impact }\end{array}$ & Journal article & Innate immunity & $\begin{array}{l}\text { Excessive activation of neutrophils may produce } \\
\text { elevated levels of toxic substances and reactive } \\
\text { oxygen species that define localized aggressive } \\
\text { periodontitis. }\end{array}$ \\
\hline 36 & $\begin{array}{l}\text { Stadler et al }{ }^{46} \\
(2016)\end{array}$ & $\begin{array}{l}\text { Gingival crevicular fluid } \\
\text { levels of cytokines/ } \\
\text { chemokines in chronic } \\
\text { periodontitis: a } \\
\text { meta-analysis }\end{array}$ & Journal article & $\begin{array}{l}\text { Adaptive } \\
\text { immunity }\end{array}$ & $\begin{array}{l}\text { Cytokines and chemokines are quickly produced } \\
\text { in the tissues of periodontal ligament and can be } \\
\text { detected continuously in the gingival crevicular } \\
\text { fluid. }\end{array}$ \\
\hline 37 & $\begin{array}{l}\text { Ford et al }{ }^{47} \\
(2010)\end{array}$ & $\begin{array}{l}\text { Immunological differ- } \\
\text { ences and similarities } \\
\text { between chronic perio- } \\
\text { dontitis and aggressive } \\
\text { periodontitis }\end{array}$ & Journal article & $\begin{array}{l}\text { Cytokines and } \\
\text { chemokines }\end{array}$ & $\begin{array}{l}\text { The inflammatory process is initiated by toll-like } \\
\text { receptors, which are specific protein structures } \\
\text { whose function, is to discover molecules released } \\
\text { by the pathologic bacteria. TLR- } 2 \text { is mainly } \\
\text { functioned to recognize the lipoproteins and } \\
\text { peptidoglycan components of the secretion of } \\
\text { subgingival bacteria, while TLR- } 4 \text { is mostly directed } \\
\text { to recognize lipopolysaccharide of gram-negative } \\
\text { bacteria. }\end{array}$ \\
\hline
\end{tabular}


Table 1 (continued)

\begin{tabular}{|c|c|c|c|c|c|}
\hline No. & Study (y) & Literature title & $\begin{array}{l}\text { Literature } \\
\text { source }\end{array}$ & $\begin{array}{l}\text { Topic in this } \\
\text { article }\end{array}$ & Findings \\
\hline 38 & $\begin{array}{l}\text { Turner et al }{ }^{48} \\
(2014)\end{array}$ & $\begin{array}{l}\text { Cytokines and chemok- } \\
\text { ines: at the crossroads } \\
\text { of cell signaling and } \\
\text { inflammatory disease }\end{array}$ & Journal article & $\begin{array}{l}\text { Cytokines and } \\
\text { chemokines }\end{array}$ & $\begin{array}{l}\text { Inflammation process is driven by a group of } \\
\text { cytokines and chemokines released continuously } \\
\text { by various immune cells. }\end{array}$ \\
\hline 39 & $\begin{array}{l}\text { Andrukhov } \\
\text { et } \mathrm{al}^{7}(2011)\end{array}$ & $\begin{array}{l}\text { Serum cytokine levels in } \\
\text { periodontitis patients in } \\
\text { relation to the bacterial } \\
\text { load }\end{array}$ & Journal article & $\begin{array}{l}\text { Cytokines and } \\
\text { chemokines }\end{array}$ & $\begin{array}{l}\text { The qualitative nature of cytokines and their con- } \\
\text { tinuous release is usually regulated by subsets of } \\
\text { CD4 }{ }^{+} \text {T lymphocytes, which are called T helper } \\
\text { cells. The different subsets of T helper cells are } \\
\text { characterized by releasing different cytokine } \\
\text { profiles with different functions in the host } \\
\text { immune response. These subsets produce dif- } \\
\text { ferent cytokines, such as interleukins, which are } \\
\text { molecules that regulate the immune response } \\
\text { and signal the release and proliferation of more } \\
\text { white blood cells. }\end{array}$ \\
\hline 40 & $\begin{array}{l}\text { Mosmann and } \\
\text { Sad }^{49}(1996)\end{array}$ & $\begin{array}{l}\text { The expanding universe } \\
\text { of T cell subsets: Th1, } \\
\text { Th2, and more }\end{array}$ & Journal article & $\begin{array}{l}\text { Cytokines and } \\
\text { chemokines }\end{array}$ & $\begin{array}{l}\text { Th1 cells release interleukins as TNF- } \alpha \text {, IL- } 12 \text {, } \\
\text { IL- } 1 \text {, IL-2, and interferon- } \gamma \text { inducing the cellular } \\
\text { immune response. Th2 cells produce IL- } 10 \text {, } \\
\text { IL-5, IL-6, IL- } 4 \text { and IL- } 13 \text { inducing the humoral } \\
\text { immune response. }\end{array}$ \\
\hline 41 & $\begin{array}{l}\text { Harrington } \\
\text { et } \mathrm{al}^{50}(2005)\end{array}$ & $\begin{array}{l}\text { Interleukin 17-pro- } \\
\text { ducing CD4+ effector } \\
\text { T cells develop via a } \\
\text { lineage distinct from the } \\
\text { T helper type } 1 \text { and } 2 \\
\text { lineages }\end{array}$ & Journal article & $\begin{array}{l}\text { Cytokines and } \\
\text { chemokines }\end{array}$ & $\begin{array}{l}\text { Th17 cells release IL-17 which is basically } \\
\text { involved in the initial inflammatory response } \\
\text { against subgingival pathogens by encouraging } \\
\text { rapid neutrophils recruitment. }\end{array}$ \\
\hline 42 & $\begin{array}{l}\text { Araujo-Pires } \\
\text { et al }{ }^{51}(2014)\end{array}$ & $\begin{array}{l}\text { Simultaneous analysis of } \\
\text { Thelper subsets (Th1, } \\
\text { Th2, Th9, Th17, Th22, } \\
\text { Tfh, Tr1, and Tregs) } \\
\text { markers expression in } \\
\text { periapical lesions reveals } \\
\text { multiple cytokine } \\
\text { clusters accountable } \\
\text { for lesions activity and } \\
\text { inactivity status }\end{array}$ & Journal article & $\begin{array}{l}\text { Cytokines and } \\
\text { chemokines }\end{array}$ & $\begin{array}{l}\text { Cytokines are proteins secreted by the inflamma- } \\
\text { tory cells into the injured tissues responding to } \\
\text { microbial compounds and other injuries through } \\
\text { leucocytes recruitment. They are continuously } \\
\text { produced by lymphocytes specially CD4 }{ }^{+} T \\
\text { lymphocytes. Cytokines play a vital role to } \\
\text { initiate and regulate the inflammatory process of } \\
\text { periodontitis through activation and differentia- } \\
\text { tion of osteoblasts, activation, and proliferation } \\
\text { of fibroblasts and production of collagen and } \\
\text { neovascularization. }\end{array}$ \\
\hline 43 & $\begin{array}{l}\text { Feghali and } \\
\text { Wright } \\
\text { (1997) }\end{array}$ & $\begin{array}{l}\text { Cytokines in acute and } \\
\text { chronic inflammation }\end{array}$ & Journal article & $\begin{array}{l}\text { Cytokines and } \\
\text { chemokines }\end{array}$ & $\begin{array}{l}\text { Inflammatory cytokines can be classified into } \\
\text { two categories: the first one is associated with } \\
\text { acute inflammation and the second is associated } \\
\text { with chronic inflammation. }\end{array}$ \\
\hline 44 & $\begin{array}{l}\text { Kleiner et al }{ }^{11} \\
(2013)\end{array}$ & $\begin{array}{l}\text { Cytokine levels in } \\
\text { the serum of healthy } \\
\text { subjects }\end{array}$ & Journal article & $\begin{array}{l}\text { Cytokines and } \\
\text { chemokines }\end{array}$ & $\begin{array}{l}\text { Cytokines are involved in regulating the } \\
\text { inflammatory response of periodontitis, which } \\
\text { is regulated by a complex network of mediators } \\
\text { and signaling pathways. }\end{array}$ \\
\hline 45 & $\begin{array}{l}\text { Buduneli and } \\
\text { Kinane }^{5}(2011)\end{array}$ & $\begin{array}{l}\text { Host-derived diagnostic } \\
\text { markers related to soft } \\
\text { tissue destruction and } \\
\text { bone degradation in } \\
\text { periodontitis }\end{array}$ & Journal article & $\begin{array}{l}\text { Cytokines and } \\
\text { chemokines }\end{array}$ & $\begin{array}{l}\text { A wide range of cytokines plays a vital role in } \\
\text { the pathophysiology of periodontitis such as } \\
\text { IL- } 1 \beta \text {, IL- } 6 \text {, TNF- } \alpha \text {, and RANKL. In addition to } \\
\text { the anti-inflammatory function of IL- } 10 \text {, it has a } \\
\text { proinflammatory role in periodontitis as well. }\end{array}$ \\
\hline 46 & $\begin{array}{l}\text { Azuma et al }{ }^{58} \\
(2014)\end{array}$ & $\begin{array}{l}\text { The role of IL- } 6 \text { on apical } \\
\text { periodontitis: a system- } \\
\text { atic review }\end{array}$ & Journal article & $\begin{array}{l}\text { Cytokines and } \\
\text { chemokines }\end{array}$ & $\begin{array}{l}\text { Chemokine receptors are found and expressed } \\
\text { on Th1 cells, Th2 cells, neutrophils, and } \\
\text { monocytes. }\end{array}$ \\
\hline 47 & $\begin{array}{l}\text { Braz-Silva et } a^{56} \\
(2019)\end{array}$ & $\begin{array}{l}\text { Inflammatory profile of } \\
\text { chronic apical periodon- } \\
\text { titis: a literature review }\end{array}$ & Journal article & $\begin{array}{l}\text { Cytokines and } \\
\text { chemokines }\end{array}$ & $\begin{array}{l}\text { Chemokines can migrate to the inflammation } \\
\text { sites "chemotaxis" which is the reason for calling } \\
\text { them "chemokines." }\end{array}$ \\
\hline
\end{tabular}


Table 1 (continued)

\begin{tabular}{|c|c|c|c|c|c|}
\hline No. & Study (y) & Literature title & $\begin{array}{l}\text { Literature } \\
\text { source }\end{array}$ & $\begin{array}{l}\text { Topic in this } \\
\text { article }\end{array}$ & Findings \\
\hline 48 & $\begin{array}{l}\text { Goldbach- } \\
\text { Mansky } \\
(2012)\end{array}$ & $\begin{array}{l}\text { Immunology in clinic } \\
\text { review series; focus } \\
\text { on autoinflammatory } \\
\text { diseases: update on } \\
\text { monogenic autoinflam- } \\
\text { matory diseases: the } \\
\text { role of interleukin (IL)-1 } \\
\text { and an emerging role for } \\
\text { cytokines beyond IL-1 }\end{array}$ & Journal article & $\begin{array}{l}\text { Cytokines and } \\
\text { chemokines }\end{array}$ & $\begin{array}{l}\text { IL- } 1 \alpha \text { and IL- } 1 \beta \text { are proved to act as strong proin- } \\
\text { flammatory molecules. }\end{array}$ \\
\hline 49 & $\begin{array}{l}\text { Silva et al }{ }^{56} \\
(2005)\end{array}$ & $\begin{array}{l}\text { Differential expression } \\
\text { of chemokines and } \\
\text { chemokine receptors in } \\
\text { inflammatory periapical } \\
\text { diseases }\end{array}$ & Journal article & $\begin{array}{l}\text { Cytokines and } \\
\text { chemokines }\end{array}$ & $\begin{array}{l}\text { Chemokines consist of two major families; } \\
\text { CXC and CC with their receptors; CXC chemok- } \\
\text { ine receptor and CC chemokine receptor, } \\
\text { respectively. }\end{array}$ \\
\hline 50 & $\begin{array}{l}\text { de Carvalho } \\
\text { Fraga et al }{ }^{60} \\
(2013)\end{array}$ & $\begin{array}{l}\text { Th1 and Th2-like protein } \\
\text { balance in human } \\
\text { inflammatory radicular } \\
\text { cysts and periapical } \\
\text { granulomas }\end{array}$ & Journal article & $\begin{array}{l}\text { Cytokines and } \\
\text { chemokines }\end{array}$ & $\begin{array}{l}\text { Th1 cells express chemokine receptors CCR5 } \\
\text { and CXCR3, while Th2 cells mainly express CCR3 } \\
\text { and CCR4. Monocytes and macrophages express } \\
\text { CCR5 and CCR2. }\end{array}$ \\
\hline 51 & $\begin{array}{l}\text { Comerford et } \\
\mathrm{al}^{55}(2011)\end{array}$ & $\begin{array}{l}\text { Mini-review series: } \\
\text { focus on chemokines }\end{array}$ & Journal article & $\begin{array}{l}\text { Cytokines and } \\
\text { chemokines }\end{array}$ & $\begin{array}{l}\text { Chemokines are a large subfamily of cytokines } \\
\text { that are composed of small proteins and associ- } \\
\text { ated with activation and migration of inflamma- } \\
\text { tory cells such as macrophages, neutrophils, and } \\
\text { lymphocytes. They include } 44 \text { members that } \\
\text { can bind to one or more } 21 \mathrm{G} \text {-protein-coupled } \\
\text { receptors. }\end{array}$ \\
\hline 52 & $\begin{array}{l}\text { Wells et al }{ }^{59} \\
\text { (1998) }\end{array}$ & $\begin{array}{l}\text { Definition, function, } \\
\text { and pathophysiological } \\
\text { significance of chemok- } \\
\text { ine receptors }\end{array}$ & Journal article & $\begin{array}{l}\text { Cytokines and } \\
\text { chemokines }\end{array}$ & $\begin{array}{l}\text { CC chemokine receptors are found and } \\
\text { expressed on a wide range of cells such as } \\
\text { macrophages, monocytes, platelets, basophils, } \\
\text { lymphocytes, and eosinophils. }\end{array}$ \\
\hline 53 & $\begin{array}{l}\text { Graves and } \\
\text { Cochran } \\
(2003)\end{array}$ & $\begin{array}{l}\text { The contribution of } \\
\text { interleukin-1 and } \\
\text { tumor necrosis factor } \\
\text { to periodontal tissue } \\
\text { destruction }\end{array}$ & Journal article & $\begin{array}{l}\text { Inflammatory } \\
\text { mediators and } \\
\text { bone resorption }\end{array}$ & $\begin{array}{l}\text { Aggravation of the inflammatory process results } \\
\text { in release of cytokines and other inflammatory } \\
\text { mediators which propagate the inflammation. } \\
\text { The failure to stop inflammation leads to expan- } \\
\text { sion of the inflammation to alveolar bone and } \\
\text { soft tissues. }\end{array}$ \\
\hline 54 & $\begin{array}{l}\text { Cochran }^{62} \\
(2008)\end{array}$ & $\begin{array}{l}\text { Inflammation and bone } \\
\text { loss in periodontal } \\
\text { disease }\end{array}$ & Journal article & $\begin{array}{l}\text { Inflammatory } \\
\text { mediators and } \\
\text { bone resorption }\end{array}$ & $\begin{array}{l}\text { Cytokines such as IL-17, IL-6, IL-1 } \beta \text {, TNF- } \alpha \text {, } \\
\text { macrophage colony-stimulating factor and } \\
\text { prostaglandin } \mathrm{E}_{2} \text { are proinflammatory mediators } \\
\text { which trigger osteoclast activity causing bone } \\
\text { resorption. } \\
\text { IL-6 is produced by different cells such as osteo- } \\
\text { blasts and fibroblasts. It plays an important role } \\
\text { in inducing osteoclast formation and promoting } \\
\text { bone resorption }\end{array}$ \\
\hline 55 & Lerner $^{63}(2006)$ & $\begin{array}{l}\text { Inflammation-induced } \\
\text { bone remodeling in per- } \\
\text { iodontal disease and the } \\
\text { influence of postmeno- } \\
\text { pausal osteoporosis }\end{array}$ & Journal article & $\begin{array}{l}\text { Inflammatory } \\
\text { mediators and } \\
\text { bone resorption }\end{array}$ & \multirow[t]{2}{*}{$\begin{array}{l}\text { During the inflammatory response, a wide array } \\
\text { of cytokines, chemokines, and many other } \\
\text { inflammatory mediators activate periosteal } \\
\text { osteoblasts altering expression levels of a protein } \\
\text { presents on the osteoblast surfaces called recep- } \\
\text { tor activator of nuclear factor-kappa B ligand. }\end{array}$} \\
\hline 56 & $\begin{array}{l}\text { Boyle et al }{ }^{64} \\
(2003)\end{array}$ & $\begin{array}{l}\text { Osteoclast differentia- } \\
\text { tion and activation }\end{array}$ & Journal article & $\begin{array}{l}\text { Inflammatory } \\
\text { mediators and } \\
\text { bone resorption }\end{array}$ & \\
\hline 57 & $\begin{array}{l}\text { Bascones et } \\
\mathrm{al}^{65}(2005)\end{array}$ & $\begin{array}{l}\text { Tissue destruction in } \\
\text { periodontitis: bacteria } \\
\text { or cytokines fault }\end{array}$ & Journal article & $\begin{array}{l}\text { Inflammatory } \\
\text { mediators and } \\
\text { bone resorption }\end{array}$ & $\begin{array}{l}\text { RANKL is a TNF- } \alpha \text { family of cytokines that } \\
\text { induces the differentiation of osteoclasts which } \\
\text { are essential for the induction of osteoclastogen- } \\
\text { esis process. }\end{array}$ \\
\hline
\end{tabular}


Table 1 (continued)

\begin{tabular}{|c|c|c|c|c|c|}
\hline No. & Study (y) & Literature title & $\begin{array}{l}\text { Literature } \\
\text { source }\end{array}$ & $\begin{array}{l}\text { Topic in this } \\
\text { article }\end{array}$ & Findings \\
\hline 58 & $\begin{array}{l}\text { Nakashima } \\
\text { et al }{ }^{66}(2000)\end{array}$ & $\begin{array}{l}\text { Protein expression and } \\
\text { functional difference } \\
\text { of membrane-bound } \\
\text { and soluble receptor } \\
\text { activator of NF-kB } \\
\text { ligand: modulation } \\
\text { of the expression by } \\
\text { osteotropic factors and } \\
\text { cytokines }\end{array}$ & Journal article & $\begin{array}{l}\text { Inflammatory } \\
\text { mediators and } \\
\text { bone resorption }\end{array}$ & $\begin{array}{l}\text { RANKL is expressed by osteoblasts beside some } \\
\text { other cells such as T lymphocytes, fibroblasts } \\
\text { and B lymphocytes. }\end{array}$ \\
\hline 59 & $\begin{array}{l}\text { Yucel-Lindberg } \\
\text { and Båge }{ }^{67} \\
\text { (2013) }\end{array}$ & $\begin{array}{l}\text { Inflammatory mediators } \\
\text { in the pathogenesis of } \\
\text { periodontitis }\end{array}$ & Journal article & $\begin{array}{l}\text { Inflammatory } \\
\text { mediators and } \\
\text { bone resorption }\end{array}$ & $\begin{array}{l}\text { The inflammatory mediator prostaglandin } \mathrm{E}_{2} \\
\text { triggers bone resorption by the upregulation } \\
\text { of RANKL expression and the inhibition of OPG } \\
\text { expression in osteoblastic cells. The stimulatory } \\
\text { effect of subgingival pathogens has been medi- } \\
\text { ated through the PGE } / \text { RANKL pathway during } \\
\text { osteoclastogenesis. } \\
\text { RANKL-stimulated osteoclastogenesis can be } \\
\text { reinforced by LPS and PGE } \text { through a series of }_{2} \\
\text { direct effects on the hematopoietic cells. PGE } \\
\text { can affect osteoclast formation. }\end{array}$ \\
\hline
\end{tabular}

Abbreviations: LFA, lymphocyte function-associated antigen; LPS, lipopolysaccharide; MMP, matrix metalloproteinase activity; MAPK, Mitogen-activated protein kinase; OPG, osteoprotegerin; PMNs, polymorphonuclear leucocytes; TLR, toll-like receptor; IFN, interferon; IL, interleukin, IP, induced protein; NF-KB, nuclear factor kappa light chain enhancer of activated B cells; PGE, ${ }_{2}$ prostaglandin E2; RA, receptor antagonist; RANKL, receptor activator of nuclear factor-KB ligand; TNF, tumor necrosis factor.

\section{Conclusion}

Periodontitis is a common inflammatory disease of the periodontium that affects a wide range of population all over the world. Periodontitis is a multifactorial disease primarily caused by subgingival microbial biofilm containing different colonies of microorganisms. It is known that periodontitis is a host-mediated process, which includes both periodontal tissue destruction and bone resorption. Periodontitis occurs due to the presence of colonies of anaerobic gram-negative bacteria. It has two major forms: chronic periodontitis and aggressive periodontitis.

In periodontitis, the pathogen releases chemicals which activate the white cells of the innate immune system to produce proinflammatory cytokines that play a vital role in the progression process of periodontitis. Moreover, these pathogens can activate the acquired immune system which in turn contributes to more and more progression of the inflammatory condition. As the immune response continues, released cytokines and chemokines can cause severe damage to the gingiva, periodontal ligaments, and alveolar bone. This causes permanent alveolar bone damage and irreversible periodontal attachment loss.

Cytokines are highly important peptide mediators responsible for cell signaling and communication. Functions of cytokines vary to include the control of cell proliferation, cell differentiation, immune responses, and inflammatory responses. Cytokines consist of a wide range including chemokines which promote chemotaxis, interleukins which are responsible for communication between white blood cells, interferons which regulate innate immunity, lymphokines, and tumor necrosis factor which have a proinflammatory activity and can cause bone resorption.
Chemokines are categorized as a large subfamily of cytokines having the ability to coordinate leukocyte recruitment and activation resulting in the pathogenesis of various human diseases that are mediated by the immune system. They are inflammatory proteins characterized by their small molecular weight and the ability to attract lymphocytes, macrophages, and neutrophils to the inflammation sites. They are also called chemotactic cytokines due to their chemotactic property in nearby responsive cells.

Damage in periodontitis can occur directly and indirectly. The direct damage is a result of the released chemicals of the pathogen, while the indirect damage is a result of the host immune response to the bacterial pathogenic chemicals. The host immune response reacts to the bacterial pathogens by releasing a group of cytokines and chemokines, which have negative effect on the periodontium causing periodontal tissue damage and bone resorption. Each type of cytokines and chemokines is secreted by specific cells and has a definite effect in the inflammatory process. Different inflammatory cells and mediators are involved in both innate and acquired immunity.

\section{Conflict of Interest}

None declared.

\section{References}

1 Newman MG, et al. Carranza's Clinical Periodontology. Elsevier Health Sciences; 2011 1305-7456

2 Pihlstrom BL, Michalowicz BS, Johnson NW. Periodontal diseases. Lancet 2005;366(9499) :1809-1820

3 Graves D. Cytokines that promote periodontal tissue destruction. J Periodontol 2008;79(8, Suppl):1585-1591 
4 Heidari Z, Moudi B, Mahmoudzadeh-Sagheb H. Immunomodulatory factors gene polymorphisms in chronic periodontitis: an overview. BMC Oral Health 2019;19(1):29

5 Buduneli N, Kinane DF. Host-derived diagnostic markers related to soft tissue destruction and bone degradation in periodontitis. J Clin Periodontol 2011;38(Suppl 11):85-105

6 Hasan A, Palmer RM. A clinical guide to periodontology: pathology of periodontal disease. Br Dent J 2014;216(8):457-461

7 Andrukhov O, Ulm C, Reischl H, Nguyen PQ, Matejka M, RauschFan X. Serum cytokine levels in periodontitis patients in relation to the bacterial load. J Periodontol 2011;82(6):885-892

8 Gemmell E, Marshall RI, Seymour GJ. Cytokines and prostaglandins in immune homeostasis and tissue destruction in periodontal disease. Periodontol 2000 1997;14(1):112-143

9 Di Benedetto A, Gigante I, Colucci S, Grano M. Periodontal disease: linking the primary inflammation to bone loss. Clin Dev Immunol 2013;2013:503754

10 Tisoncik JR, Korth MJ, Simmons CP, Farrar J, Martin TR, Katze MG. Into the eye of the cytokine storm. Microbiol Mol Biol Rev 2012;76(1):16-32

11 Kleiner G, Marcuzzi A, Zanin V, Monasta L, Zauli G. Cytokine levels in the serum of healthy subjects. Mediators Inflamm 2013;2013:434010

12 Bonecchi R, Galliera E, Borroni EM, Corsi MM, Locati M, Mantovani A. Chemokines and chemokine receptors: an overview. Front Biosci 2009;14(1):540-551

13 Armitage GC, Cullinan MP. Comparison of the clinical features of chronic and aggressive periodontitis. Periodontol 2000 2010;53(1):12-27

14 Socransky SS, Haffajee AD, Cugini MA. Smith C, Kent RL Jr. Microbial complexes in subgingival plaque. J Clin Periodontol 1998;25(2):134-144

15 Balashova N, Dhingra A, Boesze-Battaglia K, Lally ET. Aggregatibacter actinomycetemcomitans leukotoxin induces cytosol acidification in LFA-1 expressing immune cells. Mol Oral Microbiol 2016;31(1):106-114

16 Gölz L, Memmert S, Rath-Deschner B, et al. LPS from P. gingivalis and hypoxia increases oxidative stress in periodontal ligament fibroblasts and contributes to periodontitis. Mediators Inflamm 2014;2014:986264

17 Sorsa T, Mäntylä P, Tervahartiala T, Pussinen PJ, Gamonal J, Hernandez M. MMP activation in diagnostics of periodontitis and systemic inflammation. J Clin Periodontol 2011;38(9):817-819

18 Kachlany SC. Aggregatibacter actinomycetemcomitans leukotoxin: from threat to therapy. J Dent Res 2010;89(6):561-570

19 Kapoor U, Sharma G, Juneja M, Nagpal A. Halitosis: current concepts on etiology, diagnosis and management. Eur J Dent 2016;10(2):292-300

20 Song B, Zhang YL, Chen LJ, et al. The role of toll-like receptors in periodontitis. Oral Dis 2017;23(2):168-180

21 Zhang Y, Li X. Lipopolysaccharide-regulated production of bone sialoprotein and interleukin-8 in human periodontal ligament fibroblasts: the role of toll-like receptors 2 and 4 and the MAPK pathway. J Periodontal Res 2015;50(2):141-151

22 Wara-aswapati N, Chayasadom A, Surarit R, et al. Induction of toll-like receptor expression by porphyromonas gingivalis. J Periodontol 2013;84(7):1010-1018

23 Kawai T, Akira S. Differentiation, TLR signaling. Cell Death 2006;13(5):816

24 Schuch HS, Peres KG, Demarco FF, et al. Effect of life-course family income trajectories on periodontitis: birth cohort study. J Clin Periodontol 2018;45(4):394-403

25 Lertpimonchai A, Rattanasiri S, Arj-Ong Vallibhakara S, Attia J, Thakkinstian A. The association between oral hygiene and periodontitis: a systematic review and meta-analysis. Int Dent J 2017;67(6):332-343
26 Ashraf Nazir M, Almas K. Awareness about the effects of tobacco consumption on oral health and the possibility of smoking behavior among male Saudi schoolchildren. Eur J Dent 2017;11(1):29-35

27 Sakki TK, Knuuttila ML, Vimpari SS, Hartikainen MS. Association of lifestyle with periodontal health. Community Dent Oral Epidemiol 1995;23(3):155-158

28 Castro MM, Ferreira RO, Fagundes NCF, Almeida APCPSC, Maia LC, Lima RR. Association between psychological stress and periodontitis: a systematic review. Eur J Dent 2020;14(1):171-179

29 Kim J, Amar S. Periodontal disease and systemic conditions: a bidirectional relationship. Odontology 2006;94(1):10-21

30 Meyle J, Dommisch H, Groeger S, Giacaman RA, Costalonga M, Herzberg M. The innate host response in caries and periodontitis. J Clin Periodontol 2017;44(12):1215-1225

31 Kumaresan D, Balasundaram A, Naik VK, Appukuttan DP. Gingival crevicular fluid periostin levels in chronic periodontitis patients following nonsurgical periodontal treatment with low-level laser therapy. Eur J Dent 2016;10(4):546-550

32 Lindhe J, Lang NP, Karring T, Text Book of Clinical Periodontology and Implant Dentistry Copenhagen: Munksgaard; 2003

33 Cairo F, Nieri M, Gori AM, et al. Markers of systemic inflammation in periodontal patients: chronic versus aggressive periodontitis. An explorative cross-sectional study. Eur J Oral Implantology 2010;3(2):147-153

34 Giacaman RA, Asrani AC, Ross KF, Herzberg MC. Cleavage of protease-activated receptors on an immortalized oral epithelial cell line by Porphyromonas gingivalis gingipains. Microbiology 2009;155(Pt 10) :3238-3246

35 Beklen A, Hukkanen M, Richardson R, Konttinen YT. Immunohistochemical localization of toll-like receptors 1-10 in periodontitis. Oral Microbiol Immunol 2008;23(5):425-431

36 Dommisch H, Reinartz M, Backhaus T, Deschner J, Chung $\mathrm{W}$, Jepsen S. Antimicrobial responses of primary gingival cells to Porphyromonas gingivalis. J Clin Periodontol 2012;39(10):913-922

37 Hosokawa I, Hosokawa Y, Ozaki K, Yumoto H, Nakae H, Matsuo T. Proinflammatory effects of muramyldipeptide on human gingival fibroblasts. J Periodontal Res 2010;45(2):193-199

38 Baek KJ, Choi Y, Ji S. Gingival fibroblasts from periodontitis patients exhibit inflammatory characteristics in vitro. Arch Oral Biol 2013;58(10):1282-1292

39 Jung YJ, Choi YJ, An SJ, Lee HR, Jun HK, Choi BK. Tannerella forsythia GroEL induces inflammatory bone resorption and synergizes with interleukin-17. Mol Oral Microbiol 2017;32(4):301-313

40 Marki A, Esko JD, Pries AR, Ley K. Role of the endothelial surface layer in neutrophil recruitment. J Leukoc Biol 2015;98(4):503-515

41 White P, Cooper P, Milward M, Chapple I. Differential activation of neutrophil extracellular traps by specific periodontal bacteria. Free Radic Biol Med 2014;75(Suppl 1) :S53

42 White PC, Chicca IJ, Cooper PR, Milward MR, Chapple IL. Neutrophil extracellular traps in periodontitis: a web of intrigue. J Dent Res 2016;95(1):26-34

43 Alfakry H, Malle E, Koyani CN, Pussinen PJ, Sorsa T. Neutrophil proteolytic activation cascades: a possible mechanistic link between chronic periodontitis and coronary heart disease. Innate Immun 2016;22(1):85-99

44 Hajishengallis G, Chavakis T, Hajishengallis E, Lambris JD. Neutrophil homeostasis and inflammation: novel paradigms from studying periodontitis. J Leukoc Biol 2015;98(4):539-548

45 Hasturk H, Kantarci A. Activation and resolution of periodontal inflammation and its systemic impact. Periodontol 2000 2015;69(1):255-273

46 Stadler AF, Angst PD, Arce RM, Gomes SC, Oppermann RV, Susin C. Gingival crevicular fluid levels of cytokines/chemokines 
in chronic periodontitis: a meta-analysis. J Clin Periodontol 2016;43(9):727-745

47 Ford PJ, Gamonal J, Seymour GJ. Immunological differences and similarities between chronic periodontitis and aggressive periodontitis. Periodontol 2000 2010;53(1):111-123

48 Turner MD, Nedjai B, Hurst T, Pennington DJ. Cytokines and chemokines: at the crossroads of cell signalling and inflammatory disease. Biochim Biophys Acta 2014;1843(11):2563-2582

49 Mosmann TR, Sad S. The expanding universe of T-cell subsets: Th1, Th2 and more. Immunol Today 1996;17(3):138-146

50 Harrington LE, Hatton RD, Mangan PR, et al. Interleukin 17-producing CD4+ effector T cells develop via a lineage distinct from the $\mathrm{T}$ helper type 1 and 2 lineages. Nat Immunol 2005;6(11):1123-1132

51 Araujo-Pires AC, Francisconi CF, Biguetti CC, et al. Simultaneous analysis of $\mathrm{T}$ helper subsets (Th1, Th2, Th9, Th17, Th22, Tfh, Tr1 and Tregs) markers expression in periapical lesions reveals multiple cytokine clusters accountable for lesions activity and inactivity status. J Appl Oral Sci 2014;22(4):336-346

52 Feghali CA, Wright TM. Cytokines in acute and chronic inflammation. Front Biosci 1997;2(1):d12-d26

53 Preshaw PM, Taylor JJ. How has research into cytokine interactions and their role in driving immune responses impacted our understanding of periodontitis. ?J Clin Periodontol 2011;38(Suppl 11):60-84

54 Goldbach-Mansky R. Immunology in clinic review series; focus on autoinflammatory diseases: update on monogenic autoinflammatory diseases: the role of interleukin (IL)- 1 and an emerging role for cytokines beyond IL-1. Clin Exp Immunol 2012;167(3):391-404

55 Comerford I, McColl SR. Mini-review series: focus on chemokines. Immunol Cell Biol 2011;89(2):183-184

56 Braz-Silva PH, Bergamini ML, Mardegan AP. De Rosa CS, Hasseus B, Jonasson P. Inflammatory profile of chronic apical periodontitis: a literature review. Acta Odontol Scand 2019;77(3):173-180

57 Silva TA, Garlet GP, Lara VS. Martins W Jr, Silva JS, Cunha FQ. Differential expression of chemokines and chemokine receptors in inflammatory periapical diseases. Oral Microbiol Immunol 2005;20(5):310-316

58 Azuma MM, Samuel RO, Gomes-Filho JE, Dezan-Junior E, Cintra LT. The role of IL- 6 on apical periodontitis: a systematic review. Int Endod J 2014;47(7):615-621

59 Wells TN, Power CA, Proudfoot AE. Definition, function and pathophysiological significance of chemokine receptors. Trends Pharmacol Sci 1998;19(9):376-380

60 de Carvalho Fraga CA, Alves LR, de Sousa AA, et al. Th1 and Th2-like protein balance in human inflammatory radicular cysts and periapical granulomas. J Endod 2013;39(4):453-455

61 Graves DT, Cochran D. The contribution of interleukin-1 and tumor necrosis factor to periodontal tissue destruction. J Periodontol 2003;74(3):391-401

62 Cochran DL. Inflammation and bone loss in periodontal disease. J Periodontol 2008;79(8(Suppl):1569-1576

63 Lerner UH. Inflammation-induced bone remodeling in periodontal disease and the influence of post-menopausal osteoporosis. J Dent Res 2006;85(7):596-607

64 Boyle WJ, Simonet WS, Lacey DL. Osteoclast differentiation and activation. Nature 2003;423(6937) :337-342

65 Bascones A, Noronha S, Gómez M, Mota P, Gónzalez Moles MA, Villarroel Dorrego M. Tissue destruction in periodontitis: bacteria or cytokines fault? Quintessence Int 2005;36(4):299-306

66 Nakashima T, Kobayashi Y, Yamasaki S, et al. Protein expression and functional difference of membrane-bound and soluble receptor activator of NF-kappaB ligand: modulation of the expression by osteotropic factors and cytokines. Biochem Biophys Res Commun 2000;275(3):768-775

67 Yucel-Lindberg T, Båge T. Inflammatory mediators in the pathogenesis of periodontitis. Expert Rev Mol Med 2013;15:e7

68 Chatterjee D, Kapoor A, Vijay S, Sobti G, Kara D, Thanvi J. Efficacy of locally administered $1.2 \%$ rosuvastatin gel in patients with periodontitis: a randomized placebo controlled clinical trial. Eur J Dent 2019;13(1):29-35 